\title{
Analisis Proporsi Biaya Sumber Daya Manusia, Material dan Alat Pada Proyek Konstruksi Jalan
}

\author{
Berril Mufardis ${ }^{1}$ Cut Zukhrina Oktaviani ${ }^{2}$ Buraida $^{3}$ \\ ${ }^{1}$ Mahasiswa, Jurusan Teknik Sipil, Universitas Syiah Kuala, Banda Aceh 23111, Indonesia \\ 2,3 Jurusan Teknik Sipil, Universitas Syiah Kuala, Banda Aceh 23111, Indonesia. \\ Email: berrilmufardis97@gmail.com
}

\begin{abstract}
Cost Proportion of resource is a balance between the resources used in construction projects. This study aims to identify and analyze the percentage cost proportion of human resources, materials and tools on the road projects. The percentage description cost proportion of human resources, materials and tools obtained by descriptive analysis method. The data used are the Cost Budget Plan Document and the Work Unit Price Analysis Document. The research data were grouped into 3 groups based on the scope of the road project work, namely the scope road reconstruction, road rehabilitation and road improvement. The cost proportion of reconstruction, human resources 10,68\%, materials $60,41 \%$ and tools 9,26\%. Road project scope rehabilitation cost proportion of human resources 0,97\%, material 58,48\% and tools 21,35\% while the project scope of increase cost proportion of human resources 0,85\%, material 57,50\% and tools $20,49 \%$.
\end{abstract}

Keyword: Cost Proportion, Human Resources, Material Resources, Equipment Resources, Road Projects

\begin{abstract}
Abstrak
Proporsi biaya sumber daya adalah keseimbangan antara sumber daya yang digunakan pada proyek konstruksi. Penelitian ini bertujuan mengidentifikasi dan menganalisa persentase proporsi biaya sumber daya manusia, material dan alat pada proyek jalan. Gambaran persentase proporsi biaya sumber daya manusia, material dan alat diperoleh dengan metode analisis deskriptif. Data yang digunakan yaitu Dokumen Rencana Anggaran Biaya dan Dokumen Analisa Harga Satuan Pekerjaan. Data penelitian dikelompokkan kepada 3 kelompok berdasarkan lingkup pekerjaan proyek jalan yaitu lingkup rekonstruksi jalan, rehabilitasi jalan dan peningkatan jalan. Proporsi biaya lingkup rekonstruksi, sumber daya manusia 10,68\%, material 60,41\% dan alat 9,26\%. Proyek jalan lingkup rehabilitasi proporsi biaya sumber daya manusia 0,97\%, material 58,48\% dan alat 21,35\% sedangkan proyek jalan lingkup peningkatan proporsi biaya sumber daya manusia 0,85\%, material 57,50\% dan alat 20,49\%.
\end{abstract}

Kata Kunci: Proporsi Biaya, Sumber Daya Manusia,Sumber Daya Material, Sumber Daya Alat, Proyek Jalan

\section{Pendahuluan}

Proyek konstruksi merupakan pekerjaan dengan kompleksitas yang tinggi sehingga melibatkan kolaborasi berbagai macam sumber daya proyek dan membutuhkan banyak sumber daya. Kompleksitas yang tinggi membuat suatu proyek membutuhkan sistem manajemen yang baik agar sebuah proyek dapat tepat sasaran sesuai dengan rencana.

Pembangunan infrastruktur khususnya infrastruktur jalan sangat dibutuhkan dalam menghubungkan kabupaten/kota di Provinsi Aceh maka proyek konstruksi jalan harus menjadi perhatian penting karena membutuhkan biaya yang sangat besar. Berdasrkan latar belakang permasalahan tersebut, maka perlu dilakukan penelitian yang dapat memberikan gambaran persentase proporsi biaya sumber daya manusia, material dan alat pada proyek konstruksi jalan di Provinsi Aceh.

Penelitian ini bertujuan untuk mengidentifikasi dan menganalisa persentase proporsi alokasi biaya sumber daya dengan cara melakukan analisis terhadap dokumen Rencana Anggaran Biaya (RAB) dan dokumen Analisa Harga Satuan Pekerjaan (AHSP) Manfaat dari penelitian ini diharapkan memberikan gambaran persentase proporsi biaya sumber daya pada proyek konstruksi jalan di Provinsi Aceh yang meliputi sumber daya manusia, sumber daya material, sumber daya alat.

Batasan penelitian proyek yang ditinjau konstruksi jalan tahun anggaran 2015-2018 yang berlokasi di Provinsi Aceh. Ruang lingkup pekerjaan proyek konstruksi jalan yang ditinjau meliputi rekonstruksi jalan, rehabilitasi jalan dan peningkatan jalan.

\section{Tinjauan Kepustakaan}

\subsection{Pengertian Proporsi}

Kamus Besar Bahasa Indonesia [1], menjelaskan pengertian proporsi adalah keseimbangan, perbandingan dan juga yang dapat menimbulkan suatu kesatuan dan keseimbangan. Proporsi merupakan hubungan antar bagian dari suatu desain atau hubungan antara bagian dengan keseluruhan. Proporsi yang 
ditinjau pada proyek konstruksi yaitu keseimbangan antara sumber daya material, sumber daya manusia, dan sumber daya alat yang digunakan pada proyek konstruksi jalan.

\subsection{Proyek Konstruksi}

Proyek konstruksi adalah suatu rangkaian kegiatan yang saling berhubungan dengan tujuan melakukan pembangunan suatu konstruksi sesuai dengan spesifikasi yang telah ditentukan dengan sumber daya yang terbatas. Karakteristik proyek konstruksi dapat dipandang dalam tiga dimensi, yaitu : 1). Proyek bersifat unik yaitu keunikan dari proyek konstruksi adalah tidak pernah terjadi rangkaian kegiatan yang sama persis, 2). Proyek berisifat sementara dan selalu melibatkan grup pekerja yang berbeda-beda, 3). Proyek membutuhkan sumber daya (resources) yaitu setiap proyek konstruksi membutuhkan sumber daya dalam penyelesaiannya. Proyek adalah gabungan dari sumber daya-sumber daya seperti manusia, material, peralatan, dan modal/biaya yang dihimpun dalam suatu wadah organisasi sementara untuk mencapai sasaran dan tujuan yang dikutip dari Husen [2].

\subsection{Jenis Proyek Konstruksi}

Jenis proyek konstruksi dapat dibedakan menjadi dua jenis kelompok bangunan yaitu bangunan gedung dan bangunan sipil. Bangunan gedung yaitu : rumah, kantor, pabrik,sekolah dan lain-lain. Bangunan sipil yaitu jalan, jembatan, bendungan dan infrastruktur lainnya. Kelompok bangunan gedung dan bangunan sipil saling tumpang tindih, tetapi pada umumnya direncanakan dan dilaksanakan oleh disiplin ilmu perencana dan pelaksana yang berbeda yang dikutip dari Ervianto [3].

Pada penelitian ini jenis proyek konstruksi yang dijadikan obyek penelitian yaitu bangunan sipil, konstruksi jalan. Konstruksi jalan mempunyai peranan yang cukup besar dalam tatanan perkembangan pembangunan nasional. Kelompok sektor transportasi, jalan raya berpotensi sebagai penyedia akses transportasi jasa dan barang keseluruh wilayah, yang berdampak sebagai komponen akselerasi pembangunan wilayah maupun regional.

Moda transportasi darat sebagai salah satu jalan raya merupakan komponen pemicu dinamika pembangunan untuk menumbuhkan dan meningkatkan perkembangan pembangunan nasional yang dikutip dari Saodang [4].

Jalan berdasarkan jenis konstruksi perkerasan jalan dapat dibedakan menjadi tiga macam, yaitu :

1. Perkerasan Lentur (Flexibel Pavement) adalah konstruksi perkerasan yang terdiri dari lapisanlapisan perkerasan yang dihampar diatas tanah dasar yang dipadatkan.

2. Perkerasan Kaku (Rigid Pavement) adalah perkerasan yang menggunakan semen sebagai bahan pengikat.

3. Perkerasan Campuran (Composite Pavement) adalah gabungan konstruksi lapisan perkerasan kaku (Rigid pavement) dan diatasnya ditambahkan lapisan perkerasan lentur (flexibel pavement), jenis perkerasan ini bekerja sama dalam memikul beban lalu lintas.

\subsection{Sumber Daya Proyek Konstruksi}

Sumber daya proyek adalah sarana untuk menjalankan proyek agar dapat mencapai tujuan dan sasaran proyek secara efektif dan efisien. Sumber daya proyek konstruksi merupakan kemampuan dan kapasitas potensi yang dapat dimanfaatkan untuk kegiatan konstruksi yang dikutip dari Mangare [5]. Permasalahan dalam suatu proyek konstruksi bisa dihindarkan jika proporsi penggunaan sumber daya sudah optimal.

Sumber daya proyek konstruksi terdiri dari beberapa jenis diantaranya biaya, waktu, sumber daya manusia, material, dan juga peralatan yang digunakan dalam pelaksanaan proyek, dalam memanfaatkan sumber daya secara tepat dibutuhkan sistem manajemen pengelolaan sumber daya. Sumber daya diperlukan guna melaksanakan pekerjaan-pekerjaan yang merupakan komponen proyek. Proyek membutuhkan sumber daya dalam kualitas dan kuantitas yang optimal dan dapat dimobilisasi secepat mungkin.

\subsubsection{Sumber Daya Biaya (Cost Resources)}

Sumber daya biaya adalah seluruh komponen pembiayaan dalam proyek, sejak tahap perencanaan hingga berakhirnya masa pembangunan atau pelaksanaan proyek. Biaya konstruksi merupakan biaya yang dikeluarkan untuk menjalankan suatu proyek. Pada proyek konstruksi terdapat 2 biaya yaitu biaya langsung dan biaya tidak langsung.

1. Biaya Langsung adalah seluruh biaya yang berkaitan langsung dengan fisik proyek, yaitu meliputi seluruh biaya dari kegiatan yang dilakukan pada proyek (dari persiapan hingga penyelesaian) dan biaya mendatangkan seluruh sumber daya yang diperlukan oleh proyek tersebut. Biaya langsung dapat dihitung dengan mengalikan volume pekerjaan dengan harga satuan pekerjaan. Biaya langsung ini juga biasa disebut dengan biaya tidak tetap (variokjuable cost), karena sifat biaya ini tipa bulannya jumlahnya tidak tetap, tetapi berubah-ubah sesuai dengan kemajuan pekerjaan.

2. Biaya tidak langsung adalah seluruh biaya yang terkait secara tidak langsung, yang dibebankan kepada biaya proyek. Biaya ini biasanya terjadi diluar proyek namun harus ada dan tidak dapat dilepaskan dari proyek tersebut. Biaya ini meliputi antara lain pajak (tax), biaya risiko (overhead) dan biaya keuntungan (profit).

Nilai/biaya keuntungan kontraktor pada umumnya dinyatakan sebagai persentase dari seluruh jumlah pembiayaan nilai kontrak proyek. Prinsip penetapan besarnya keuntungan dipengaruhi oleh besarnya risiko atau kesulitan-kesulitan yang akan dihadapi dan sering kali tidak nampak nyata, sebagai contoh yaitu keterlambatan pihak pemberi tugas dalam melaksanakan tugas untuk membayar pekerjaan dan sebagainya. 


\subsubsection{Sumber Daya Waktu (Time Resources)}

Sumber daya waktu pada proyek konstruksi yaitu pengelolaan terhadap waktu yang diguanakan dalam pelaksanaan proyek konstruksi agar dapat selesai tepat waktu sesuai dengan rencana. Untuk menghasilkan proyek yang tepat waktu maka diperlukan perencanaan dan pengendalian waktu yang dilakukan dengan cara mengatur jadwal setiap kegiatan kapan pekerjaan dimulai dan kapan berakhir. Waktu sangat berkaitan dengan biaya dikarenakan jika terjadi keterlambatan penyelesaian proyek maka akan membuat biaya menjadi lebih besar karena membutuhkan penambahan jam kerja, operasional alat berat, pembayaran denda kontrak, dan hal lainnya.

\subsubsection{Sumber Daya Manusia (Human Resources)}

Sumber daya manusia pada proyek konstruksi yaitu melakukan pengelolaan terhadap tenaga kerja/manusia yang ada pada sebuah perusahaan konstruksi untuk melakukan pekerjaan sesuai dengan bidang ilmunya sehingga proyek dapat berjalan sesuai dengan rencana. Untuk melakukan pengelolaan tenaga kerja secara efektif dan efesien, maka diperlukan perhitungan terhadap kebutuhan tenaga kerja untuk masing-masing proyek yang dikerjakan oleh perusahaan konstruksi. Jumlah tenaga kerja telah ditentukan maka dilakukan analisis jabatan sesuai dengan bidang dan keahlian yang dimiliki oleh tenaga kerja.

\subsubsection{Sumber Daya Material (Material Resources)}

Sumber daya material pada proyek konstruksi yaitu material yang digunakan untuk melakukan kegiatan pembangunan proyek konstruksi. Material merupakan sumber daya utama dalam pelaksanaan proyek konstruksi yang dikutip dari Muzayanah [6].

\subsubsection{Sumber Daya Alat (Equipment Resources)}

Sumber daya alat pada proyek konstruksi yaitu pengelolaan terhadap alat berat baik milik perusahaan sendiri maupun yang disewa untuk digunakan dalam pelaksanaan proyek konstruksi dapat digunakan secara maksimal. Untuk mengantisipasi penumpukaan alat berat dilapangan maka dilakukan perhitungan kebutuhan alat berat dan penjadwalan masuk/keluar alat berat dari lokasi proyek konstruksi.

Faktor yang mempengaruhi pemilihan alat berat dilakukan pada tahap perencanaan, faktor dalam pemilihan alat berat yaitu jenis, jumlah dan kapasitas alat merupakan faktor-faktor penentu yang dikutip dari Rostiyanti [7]. Dalam pemilihan alat berat, ada beberapa faktor yang harus diperhatikan sehingga kesalahan dalam pemilihan alat dapat dihindari. Faktor-faktor tersebut yaitu fungsi yang harus dilaksanakan seperti kapasitas peralatan, cara operasi, pembatasan dari metode yang dipakai, ekonomi, jenis proyek, lokasi proyek, jenis daya dukung tanah dan kondisi lapangan.

\subsection{Teknik Pengumpulan Data}

Teknik pengumpulan data melalui kajian dokumen merupakan sarana dalam mengumpulkan data atau informasi dengan cara membaca surat-surat, pengumuman, iktisar rapat, pernyataan tertulis kebijakan tertentu dan bahan-bahan tulisan lainnya yang dikutip dari Sarwono [8]. Metode pencarian data ini sangat bermanfaat karena dapat dilakukan tanpa menggangu obyek atau suasana penelitian.

\subsection{Analisis Deskriptif}

Teknik analisis data adalah proses pengorganisasian dan mengurutkan data kedalam pola, kategori dan satuan uraian dasar sehingga dapat ditemukan tema dan tempat dirumuskan hipotesis kerja seperti yang disarankan oleh data. Analisa deksriptif dimaksudkan untuk menganalisa data yang terkumpul sebagaimana adanya tanpa bermaksud membuat suatu kesimpulan yang berlaku untuk umum atau generalisasi.

\section{Metode Penelitian}

\subsection{Obyek Penelitian}

Obyek Penelitian ini yaitu proyek konstruksi jalan yang dilaksanakan pada tahun 2015 sampai dengan tahun 2018 di Provinsi Aceh. Ruang lingkup pekerjaan proyek konstruksi jalan yang ditinjau meliputi rekonstruksi jalan, rehabilitasi jalan dan peningkatan jalan. Status jalan yang ditinjau yaitu jalan nasional, jalan provinsi dan jalan kabupaten.

\subsection{Jenis dan Sumber Data}

Jenis data pada penelitian ini yaitu data dokumen kontrak konstruksi berisi dokumen Rencana Anggaran Biaya (RAB) dan dokumen Analisa Harga Satuan Pekerjaan (AHSP). Sumber data menggunakan data sekunder yang diperoleh dari Dinas Pekerjaan Umum dan Penataan Ruang Provinsi Aceh, Balai Pelaksanaan Jalan Nasional 1 Banda Aceh dan Kontraktor

\subsection{Teknik Pengumpulan Data}

Penelitian ini menggunakan teknik dokumentasi, yaitu proses untuk memperoleh keterangan untuk tujuan penelitian yang berasal dari data yang berbentuk arsip (dokumen), karena dokumen merupakan sumber data yang berupa bahasa tertulis, foto atau dokumen elektronik. Metode pengumpulan data ini sangat bermanfaat karena dapat dilakukan dengan tanpa menggangu obyek atau suasana penelitian. Data yang digunakan yaitu dokumen kontrak proyek konstruksi jalan yang berisi Dokumen Rencana Anggaran Biaya (RAB) dan Dokumen Analisa Harga Satuan Pekerjaan (AHSP), data tersebut diperoleh dari Dinas Pekerjaan Umum dan Penataan Ruang Provinsi Aceh, Balai Pelaksanaan Jalan Nasional 1 Banda Aceh dan Kontraktor.

\subsection{Teknik Analisis}

Analisis data yang digunakan dalam penelitian ini yaitu menggunakan analisis deksriptif, dimana tujuan dari analisis ini adalah untuk menggambarkan secara sistematis, faktual dan akurat mengenai fakta-fakta serta hubungan antara fenomena yang diselidiki. Teknik 
analisis deskriptif dipakai untuk melihat hasil dari analisis data kontrak proyek konstruksi.

\subsubsection{Analisis Dokumen Rencana Anggaran Biaya}

Analisis dokumen Rencana Anggaran Biaya (RAB) dilakukan dengan cara menelaah informasi dan menghitung kebutuhan volume proyek dan harga dari setiap item-item pekerjaan. Data RAB yang telah dikumpulkan akan terdapat rekapitulasi divisi-divisi pekerjaan dan biaya pada setiap divisi pekerjaan tersebut. Dokumen RAB yang telah dikumpulkan dilakukan pengelompokkan data divisi-divisi yang terdapat pekerjaan pada kontrak proyek kemudian dalam divisi-divisi tersebut terbagi lag i kepada sub-sub divisi/ item pekerjaan yang memiliki volume pekerjaan, harga pekerjaan dan total harga pekerjaan.

\subsubsection{Analisis Dokumen Analisa Harga Satuan \\ Pekerjaan}

Analisa dokumen analisa harga satuan pekerjaan (AHSP) dilakukan dengan melihat kebutuhan biaya yang dibutuhkan tiap sumber daya material, sumber daya manusia, dan sumber daya alat. Dokumen AHSP terdapat analisa-analisa yang mengandung koefisien dan harga untuk sumber daya manusia, material dan alat. Sumber daya proyek tersebut kemudian dilakukan perhitungan untuk semua item pekerjaan yang terdapat pada suatu proyek konstruksi.

Analisis proporsi biaya sumber daya/langsung proyek dilakukan setelah dihitung alokasi biaya setiap komponen yang terdapat pada sumber daya manusia, sumber daya material dan sumber daya alat. Alokasi biaya pada setiap sumber daya kemudian dilakukan pengolahan sehingga diperoleh persentase proporsi 13 sampel proyek. Nilai persentase proporsi biaya yang telah didapatkan hasil yang bervariasi pada sumber daya manusia, sumber daya material dan sumber daya alat.

Nilai proporsi biaya yang telah didapatkan pada 13 sampel dikelompokkan menjadi 3 kelompok yaitu proporsi biaya untuk proyek jalan dengan ruang lingkup 1) rekonstruksi, 2) rehabilitasi dan 3) peningkatan. Pengelompokan hasil penelitian berdasarkan ruang lingkup yang sejenis maka hasil penelitian menjadi valid.

Pembiayaan pada proyek konstruksi tidak hanya terdapat biaya sumber daya/langsung tetapi juga termasuk biaya non sumber daya/tidak langsung. Biaya langsung (sumber daya) meliputi biaya sumber daya manusia, sumber daya material dan sumber daya alat. Biaya tidak langsung (non sumber daya) meliputi biaya pajak (tax), biaya keuntungan (profit) dan biaya risiko (overhead). Analisis klasifikasi biaya dilakukan dengan cara melakukan penjumlahan kebutuhan biaya langsung (sumber daya) dan biaya tidak langsung (non sumber daya).

\section{Hasil dan Pembahasan}

\subsection{Hasil Pengumpulan Data}

Data dikumpulkan diperoleh dari pihak-pihak yaitu Balai Pelaksanaan Jalan Nasional (BPJN) 1 Banda
Aceh, Dinas Pekerjaan Umum dan Perumahan Rakyat Provinsi Aceh (PUPR) Provinsi Aceh, dan Kontraktor. Data yang terkumpul sebanyak 13 sampel proyek. Rekapitulasi data kontrak proyek dapat dilihat pada Tabel 1

Tabel 1 Rekapitulasi Data Kontrak Proyek

\begin{tabular}{crrr}
\hline Kode & Tahun & $\begin{array}{c}\text { Nilai Kontrak } \\
(\mathrm{Rp})\end{array}$ & Lokasi \\
\hline A & 2016 & 17.57 .9501 .000 & Aceh Jaya \\
\hline B & 2018 & 5.889 .835 .000 & Pidie \\
\hline C & 2018 & 24.247 .475 .000 & Aceh Besar \\
\hline D & 2018 & 15.507 .903 .000 & Aceh Barat \\
\hline E & 2018 & 17.800 .836 .000 & Pidie \\
\hline F & 2018 & 6.611 .950 .000 & Pidie \\
\hline G & 2018 & 17.276 .052 .000 & Aceh Besar \\
\hline H & 2018 & 4.710 .000 .000 & Pidie \\
\hline I & 2018 & 4.173 .113 .000 & Banda Aceh \\
\hline J & 2015 & 27.604 .862 .000 & Aceh Utara \\
\hline K & 2017 & 1.210 .633 .000 & Aceh Barat \\
\hline L & 2016 & 1.382 .041 .000 & Aceh Barat \\
\hline M & 2016 & 741.066 .000 & Aceh Barat \\
\hline
\end{tabular}

\subsubsection{Gambaran Umum Objek Penelitian}

Obyek penelitian yang dijadikan sampel proyek pada penlitian ini yaitu proyek konstruksi jalan yang telah dilakukan pelaksanaan pada tahun angggaran 2015 sampai dengan tahun 2018. Waktu pelaksanaaan bervariasi dari paling singkat 60 hari sampai dengan paling lama 300 hari. Nilai kontrak proyek dimulai dari paling kecil Rp741.066.000,00 sampai dengan nilai kontrak paling besar Rp27.604.862.000,00.

Lokasi obyek penelitian tersebar di Provinsi Aceh tepatnya berada di Kabupaten Aceh Jaya, Kabupaten Pidie, Kabupaten Aceh Besar, Kabupaten Aceh Barat, Kota Banda Aceh dan Kabupaten Aceh Utara.

\subsection{Analisis Proporsi Biaya Proyek}

Analisis proporsi biaya dilakukan setelah perhitungan alokasi biaya yang terdapat pada sumber daya manusia, sumber daya material dan sumber daya alat.

\subsubsection{Analisis Proporsi Biaya Proyek Jalan Ruang Lingkup Rekonstruksi}

Proyek konstruksi jalan dengan ruang lingkup rekonstruksi merupakan proyek perbaikan untuk kategori kerusakan berat pada konstruksi jalan sehingga diperlukan pembangunan ulang pada konstruksi jalan. Alokasi biaya pada setiap sumber daya kemudian dilakukan pengolahan sehingga diperoleh persentase 
proporsi biaya sumber daya proyek pada 13 sampel proyek. Hasil analisis proporsi biaya pada proyek konstruksi jalan dengan ruang lingkup rekonstruksi jalan dapat dilihat pada Tabel 2

Tabel 2 Proporsi Biaya Sumber Daya Rekonstruksi

\begin{tabular}{ccccc}
\hline \multirow{2}{*}{ Kode } & \multirow{2}{*}{$\begin{array}{c}\text { Nilai Kontrak } \\
(\mathrm{Rp})\end{array}$} & \multicolumn{3}{c}{$\begin{array}{c}\text { Sumber Daya Proyek } \\
(\%)\end{array}$} \\
\cline { 3 - 5 } & & SDM & Bahan & Alat \\
\hline A & 17.579 .501 .000 & 10,68 & 60,41 & 9,26 \\
\hline
\end{tabular}

Berdasarkan hasil penelitian maka diperoleh hasil persentase proporsi biaya sumber daya/langsung untuk proyek konstruksi jalan dengan ruang lingkup pekerjaan rekonstruksi jalan diperoleh hasil sebagai berikut :

1. Sumber daya manusia sebesar $10,68 \%$

2. Sumber daya material sebesar $60,41 \%$

3. Sumber daya alat sebesar $9,26 \%$

Berikut ini merupakan nilai proporsi biaya non sumber daya/tidak langsung pada proyek konstruksi jalan jalan dengan ruang lingkup pekerjaan rekonstruksi jalan dapat dilihat pada pada tabel 3

Tabel 3 Proporsi Biaya Non Sumber Daya Rekonstruksi

$\begin{array}{cccc}\text { Kode } & \text { Klasifikasi } & \text { Jenis } & \text { Proporsi } \\ \text { Biaya } & \text { Biaya } & (\%)\end{array}$

\begin{tabular}{|c|c|c|c|}
\hline \multirow{5}{*}{ A } & \multirow{3}{*}{$\begin{array}{l}\text { Biaya } \\
\text { Sumber } \\
\text { Daya }\end{array}$} & Manusia & 10,68 \\
\hline & & Material & 60,41 \\
\hline & & Alat & 9,59 \\
\hline & \multirow{2}{*}{$\begin{array}{c}\text { Biaya Non } \\
\text { Sumber } \\
\text { Daya }\end{array}$} & PPN & 9,09 \\
\hline & & $\begin{array}{l}\text { Overhead } \\
\text { dan Profit }\end{array}$ & 10,23 \\
\hline & Persentase $\mathrm{T}$ & tal & 100,00 \\
\hline
\end{tabular}

\subsubsection{Analisis Proporsi Biaya Proyek Jalan Ruang Lingkup Rehabilitasi}

Proyek konstruksi jalan dengan ruang lingkup rehabilitasi jalan merupakan proyek perbaikan untuk kategori kerusakan ringan pada konstruksi jalan sehingga diperulakan perbaikan pada konstruksi jalan. Hasil analisis proporsi biaya pada proyek konstruksi jalan dengan ruang lingkup rekonstruksi jalan dapat dilihat pada Tabel 4

Tabel 4 Proporsi Biaya Sumber Daya Rehabilitasi

\begin{tabular}{ccccc}
\hline \multirow{2}{*}{ Kode } & $\begin{array}{c}\text { Nilai Kontrak } \\
(\mathrm{Rp})\end{array}$ & \multicolumn{3}{c}{$\begin{array}{c}\text { Sumber Daya Proyek } \\
(\%)\end{array}$} \\
\cline { 3 - 5 } & & SDM & Bahan & Alat \\
\hline C & 24.247 .475 .000 & 1,27 & 47,92 & 26,72 \\
\hline D & 15.507 .903 .000 & 1,12 & 55,35 & 23,11 \\
\hline E & 17.800 .836 .000 & 0,69 & 65,99 & 16,99 \\
\hline G & 17.276 .052 .000 & 1,15 & 64,26 & 21,33 \\
\hline J & 27.604 .862 .000 & 0,61 & 58,89 & 18,60 \\
\hline
\end{tabular}

Rata-rata (\%)

$0,97 \quad 58,48 \quad 21,35$

Berdasarkan hasil penelitian maka diperoleh hasil persentase proporsi biaya sumber daya/langsung untuk proyek konstruksi jalan dengan ruang lingkup pekerjaan rekonstruksi jalan pada 5 sampel proyek konstruksi jalan diperoleh hasil bervariasi sehingga dilakukan pengambilan nilai rata-rata sebagai berikut :

1. Sumber daya manusia sebesar $0,97 \%$

2. Sumber daya material sebesar $58,48 \%$

3. Sumber daya alat sebesar $21,35 \%$

Berikut ini merupakan nilai proporsi biaya non sumber daya/tidak langsung pada proyek konstruksi jalan jalan dengan ruang lingkup pekerjaan rehabilitasi jalan dapat dilihat pada pada tabel 5

Tabel 5 Proporsi Biaya Non Sumber Daya Rehabilitasi

$$
\begin{array}{ccc}
\text { Klasifikasi } \\
\text { Biaya }
\end{array} \quad \text { Jenis Biaya } \quad \begin{gathered}
\text { Proporsi } \\
(\%)
\end{gathered}
$$

\begin{tabular}{|c|c|c|c|}
\hline \multirow{5}{*}{$\mathrm{C}$} & \multirow{3}{*}{$\begin{array}{c}\text { Biaya } \\
\text { Sumber } \\
\text { Daya }\end{array}$} & Manusia & 1,27 \\
\hline & & Material & 47,92 \\
\hline & & Alat & 26,99 \\
\hline & \multirow{2}{*}{$\begin{array}{c}\text { Biaya Non } \\
\text { Sumber } \\
\text { Daya }\end{array}$} & PPN & 9,09 \\
\hline & & $\begin{array}{l}\text { Overhead } \\
\text { dan Profit }\end{array}$ & 14,74 \\
\hline & \multicolumn{2}{|c|}{ Persentase Total } & 100,00 \\
\hline \multirow{5}{*}{$\mathrm{D}$} & \multirow{3}{*}{$\begin{array}{l}\text { Biaya } \\
\text { Sumber } \\
\text { Daya }\end{array}$} & Manusia & 1,12 \\
\hline & & Material & 55,35 \\
\hline & & Alat & 23,46 \\
\hline & \multirow{2}{*}{$\begin{array}{l}\text { Biaya Non } \\
\text { Sumber } \\
\text { Daya }\end{array}$} & PPN & 9,09 \\
\hline & & $\begin{array}{l}\text { Overhead } \\
\text { dan Profit }\end{array}$ & 10,98 \\
\hline & \multicolumn{2}{|c|}{ Persentase Total } & 100,00 \\
\hline \multirow{5}{*}{$\mathrm{E}$} & \multirow{3}{*}{$\begin{array}{c}\text { Biaya } \\
\text { Sumber } \\
\text { Daya }\end{array}$} & Manusia & 0,69 \\
\hline & & Material & 65,99 \\
\hline & & Alat & 17,89 \\
\hline & \multirow{2}{*}{$\begin{array}{c}\text { Biaya Non } \\
\text { Sumber } \\
\text { Daya }\end{array}$} & PPN & 9,09 \\
\hline & & $\begin{array}{l}\text { Overhead } \\
\text { dan Profit }\end{array}$ & 6,34 \\
\hline & \multicolumn{2}{|c|}{ Persentase Total } & 100,00 \\
\hline & \multirow{3}{*}{$\begin{array}{c}\text { Biaya } \\
\text { Sumber } \\
\text { Daya }\end{array}$} & Manusia & 1,15 \\
\hline & & Material & 64,26 \\
\hline & & Alat & 22,01 \\
\hline & \multirow{2}{*}{$\begin{array}{l}\text { Biaya Non } \\
\text { Sumber } \\
\text { Daya }\end{array}$} & PPN & 9,09 \\
\hline & & $\begin{array}{l}\text { Overhead } \\
\text { dan Profit }\end{array}$ & 3,49 \\
\hline & \multicolumn{2}{|c|}{ Persentase Total } & 100,00 \\
\hline \multirow{4}{*}{$\mathrm{J}$} & \multirow{4}{*}{$\begin{array}{c}\text { Biaya } \\
\text { Sumber } \\
\text { Daya }\end{array}$} & Manusia & 0,61 \\
\hline & & Material & 58,89 \\
\hline & & Alat & 19,40 \\
\hline & & PPN & 9,09 \\
\hline
\end{tabular}




\begin{tabular}{ccc}
\hline $\begin{array}{c}\text { Biaya Non } \\
\text { Sumber } \\
\text { Daya }\end{array}$ & $\begin{array}{l}\text { Overhead } \\
\text { dan Profit }\end{array}$ & 12,01 \\
\hline Persentase Total & 100,00
\end{tabular}

\subsubsection{Analisis Proporsi Biaya Proyek Jalan Ruang Lingkup Peningkatan}

Proyek konstruksi jalan dengan ruang lingkup peningkatan jalan merupakan proyek peningkatan kemampuan pada konstruksi jalan sehingga diperlukan peningkatan kemampuan pada konstruksi jalan. Hasil analisis proporsi biaya pada proyek konstruksi jalan dengan ruang lingkup peningkatan jalan dapat dilihat pada tabel 6

Tabel 6 Proporsi Biaya Sumber Daya Peningkatan

\begin{tabular}{|c|c|c|c|c|}
\hline \multirow{2}{*}{ Kode } & \multirow{2}{*}{$\begin{array}{l}\text { Nilai Kontrak } \\
\text { (Rp) }\end{array}$} & \multicolumn{3}{|c|}{$\begin{array}{c}\text { Sumber Daya Proyek } \\
(\%)\end{array}$} \\
\hline & & SDM & Bahan & Alat \\
\hline B & 5.889 .835 .000 & 1,09 & 66,45 & 10,82 \\
\hline $\mathrm{F}$ & 6.611 .950 .000 & 1,24 & 63,26 & 13,62 \\
\hline $\mathrm{H}$ & 4.710 .000 .000 & 1,00 & 62,92 & 14,05 \\
\hline I & 4.173 .113 .000 & 1,21 & 46,01 & 34,69 \\
\hline $\mathrm{K}$ & 1.210 .633 .000 & 0,20 & 55,74 & 25,57 \\
\hline $\mathrm{L}$ & 1.382 .041 .000 & 0,72 & 52,89 & 24,42 \\
\hline $\mathrm{M}$ & 741.066 .000 & 0,50 & 55,19 & 20,26 \\
\hline \multicolumn{2}{|c|}{ Rata-rata (\%) } & 0,85 & 57,50 & 20,49 \\
\hline
\end{tabular}

Berdasarkan hasil penelitian maka diperoleh hasil persentase proporsi biaya sumber daya/langsung untuk proyek konstruksi jalan dengan ruang lingkup pekerjaan rekonstruksi jalan pada 7 sampel proyek konstruksi jalan diperoleh hasil bervariasi sehingga dilakukan pengambilan nilai rata-rata sebagai berikut :

1. Sumber daya manusia sebesar $0,85 \%$

2. Sumber daya material sebesar $57,50 \%$

3. Sumber daya alat sebesar $20,49 \%$

Berikut ini merupakan nilai proporsi biaya non sumber daya/tidak langsung pada proyek konstruksi jalan jalan dengan ruang lingkup pekerjaan peningkatan jalan dapat dilihat pada pada tabel 7

Tabel 7 Proporsi Biaya Non Sumber Daya Peningkatan

$\begin{array}{cccc}\text { Kode } & \text { Klasifikasi } & \text { Jenis } & \text { Proporsi } \\ \text { Biaya } & \text { Biaya } & (\%)\end{array}$

\begin{tabular}{|c|c|c|c|}
\hline \multirow{5}{*}{ B } & \multirow{3}{*}{$\begin{array}{l}\text { Biaya } \\
\text { Sumber } \\
\text { Daya }\end{array}$} & Manusia & 1,09 \\
\hline & & Material & 66,45 \\
\hline & & Alat & 12,33 \\
\hline & Biaya Non & PPN & 9,09 \\
\hline & $\begin{array}{c}\text { Sumber } \\
\text { Daya }\end{array}$ & $\begin{array}{l}\text { Overhead } \\
\text { dan Profit }\end{array}$ & 11,04 \\
\hline $\mathrm{F}$ & & Manusia & 1,24 \\
\hline
\end{tabular}

\begin{tabular}{|c|c|c|c|}
\hline & \multirow{2}{*}{$\begin{array}{c}\text { Biaya } \\
\text { Sumber } \\
\text { Daya }\end{array}$} & Material & 63,26 \\
\hline & & Alat & 15,21 \\
\hline & \multirow{2}{*}{$\begin{array}{l}\text { Biaya Non } \\
\text { Sumber } \\
\text { Daya }\end{array}$} & PPN & 9,09 \\
\hline & & $\begin{array}{l}\text { Overhead } \\
\text { dan Profit }\end{array}$ & 11,19 \\
\hline \multirow{5}{*}{$\mathrm{H}$} & \multirow{3}{*}{$\begin{array}{c}\text { Biaya } \\
\text { Sumber } \\
\text { Daya }\end{array}$} & Manusia & 1,00 \\
\hline & & Material & 62,92 \\
\hline & & Alat & 14,05 \\
\hline & \multirow{2}{*}{$\begin{array}{c}\text { Biaya Non } \\
\text { Sumber } \\
\text { Daya }\end{array}$} & PPN & 9,09 \\
\hline & & $\begin{array}{l}\text { Overhead } \\
\text { dan Profit }\end{array}$ & 12,93 \\
\hline \multirow{5}{*}{ I } & \multirow{3}{*}{$\begin{array}{c}\text { Biaya } \\
\text { Sumber } \\
\text { Daya }\end{array}$} & Manusia & 1,21 \\
\hline & & Material & 46,01 \\
\hline & & Alat & 35,61 \\
\hline & \multirow{2}{*}{$\begin{array}{c}\text { Biaya Non } \\
\text { Sumber } \\
\text { Daya }\end{array}$} & PPN & 9,09 \\
\hline & & $\begin{array}{l}\text { Overhead } \\
\text { dan Profit }\end{array}$ & 8,09 \\
\hline \multirow{5}{*}{ K } & \multirow{3}{*}{$\begin{array}{c}\text { Biaya } \\
\text { Sumber } \\
\text { Daya }\end{array}$} & Manusia & 0,20 \\
\hline & & Material & 55,74 \\
\hline & & Alat & 27,60 \\
\hline & \multirow{2}{*}{$\begin{array}{l}\text { Biaya Non } \\
\text { Sumber } \\
\text { Daya }\end{array}$} & PPN & 9,09 \\
\hline & & $\begin{array}{l}\text { Overhead } \\
\text { dan Profit }\end{array}$ & 7,37 \\
\hline \multirow{5}{*}{$\mathrm{L}$} & \multirow{3}{*}{$\begin{array}{l}\text { Biaya } \\
\text { Sumber } \\
\text { Daya }\end{array}$} & Manusia & 0,72 \\
\hline & & Material & 52,89 \\
\hline & & Alat & 26,85 \\
\hline & \multirow{2}{*}{$\begin{array}{c}\text { Biaya Non } \\
\text { Sumber } \\
\text { Daya }\end{array}$} & PPN & 9,09 \\
\hline & & $\begin{array}{l}\text { Overhead } \\
\text { dan Profit }\end{array}$ & 10,45 \\
\hline \multirow{5}{*}{ M } & \multirow{3}{*}{$\begin{array}{c}\text { Biaya } \\
\text { Sumber } \\
\text { Daya }\end{array}$} & Manusia & 0,50 \\
\hline & & Material & 55,19 \\
\hline & & Alat & 23,81 \\
\hline & \multirow{2}{*}{$\begin{array}{c}\text { Biaya Non } \\
\text { Sumber } \\
\text { Daya }\end{array}$} & PPN & 9,09 \\
\hline & & $\begin{array}{l}\text { Overhead } \\
\text { dan Profit }\end{array}$ & 11,41 \\
\hline
\end{tabular}

\subsection{Pembahasan}

Hasil penelitian biaya sumber daya/langsung telah didapatkan persentase proporsi biaya proyek konstruksi jalan dengan ruang lingkup pekerjaan rekonstruksi jalan didapatkan hasil proporsi biaya sumber daya manusia sebesar $10,68 \%$, sumber daya material sebesar $60,41 \%$, dan sumber daya alat sebesar 9,26\%. Hasil penelitian pada proyek konstruksi jalan dengan ruang lingkup pekerjaan rehabilitasi jalan pada 5 sampel proyek bervariasi sehingga dilakukan pengambilan hasil rata-rata proporsi biaya sumber daya manusia sebesar $0,97 \%$, sumber daya material sebesar $58,48 \%$ dan sumber daya alat sebesar $21,35 \%$. Hasil penelitian pada proyek konstruksi dengan ruang lingkup pekerjaan peningkatan jalan pada 7 sampel proyek bevariasi sehingga dilakukan pengambilan hasil ratarata proporsi biaya sumber daya manusia sebesar $0,85 \%$, 
sumber daya material sebesar $57,50 \%$ dan sumber daya alat sebesar $20,49 \%$.

\section{Kesimpulan dan Saran}

\subsection{Kesimpulan}

Kesimpulan yang dapat diambil dari hasil penelitian mengenai proporsi biaya sumber daya proyek konstruksi jalan adalah sebagai berikut :

1. Hasil analisis data dari 13 sampel proyek terbagi kepada 3 kelompok data hasil penelitian yaitu :

a).Proyek jalan ruang lingkup rekonstruksi

b).Proyek jalan ruang lingkup rehabiltiasi

c).Proyek jalan ruang lingkup peningkatan jalan

2. Pembiayaan pada proyek konstruksi tidak hanya terdapat biaya sumber daya/langsung tetapi juga termasuk biaya non sumber daya/tidak langsung.

3. Klasifikasi biaya pada proyek konstruksi ruang lingkup pekerjaan rekonstruksi jalan proporsi biaya sumber daya/langsung sebesar $80,68 \%$ dan biaya non sumber daya/tidak langsung sebesar 19,32\%. Proyek konstruksi dengan ruang lingkup pekerjaan rehabilitasi jalan proporsi biaya sumber daya/langsung sebesar $83,22 \%$ dan biaya non sumber daya/tidak langsung sebesar $18,60 \%$.

4. Hasil penelitian sumber daya/langsung telah didapatkan persentase proporsi biaya proyek konstruksi jalan dengan ruang lingkup pekerjaan rekonstruksi jalan pada 1 sampel proyek didapatkan hasil proporsi biaya sumber daya manusia sebesar $10,68 \%$, sumber daya material sebesar $60,41 \%$, dan sumber daya alat sebesar $9,2 \%$.

5. Hasil penelitian sumber daya/langsung telah didapatkan persentase proporsi biaya proyek konstruksi jalan dengan ruang lingkup pekerjaan rehabilitasi jalan pada 5 sampel proyek didapatkan hasil rata-rata proporsi biaya sumber daya manusia sebesar 0,97\%, sumber daya material sebesar $58,48 \%$ dan sumber daya alat sebesar $21,35 \%$

6. Hasil penelitian sumber daya/langsung telah didapatkan persentase proporsi biaya proyek konstruksi jalan dengan ruang lingkup pekerjaan peningkatan struktur jalan pada 7 sampel proyek didapatkan hasil rata-rata proporsi biaya sumber daya manusia sebesar $0,85 \%$, sumber daya material sebesar $57,50 \%$ dan sumber daya alat sebesar $20,49 \%$.

\subsection{Saran}

Saran didapatkan dari hasil penelitian ini, maka didapatkan beberapa saran yang menjadi pertimbangan untuk studi selanjutnya adalah sebagai berikut :
1. Hasil analisis data telah diperoleh gambaran persentase proyek dapat dilakukan pengembangan lebih lanjut menjadi pemodelan untuk mendapatkan hasil matematis dan diperoleh nilai proporsi yang tepat untuk sumber daya manusia, material dan sumber daya alat.

2. Ruang lingkup pekerjaan pada proyek konstruksi jalan yang berbeda membuat hasil penelitian nilai proporsi berbeda maka perlu dilakukan penelitian pada ruang lingkup pekerjaan lainnya.

3. Jenis proyek pada penelitian ini terbatas pada proyek konstruksi jalan, maka diperlukan penelitian pada jenis proyek konstruksi lainnya seperti proyek konstruksi jembatan, bangunan gedung dan konstruksi lainnya

\section{Daftar Kepustakaan}

[1] Kamus Besar Bahasa Indonesia (KBBI) (online),(https://kbbi.kemdikbud.go.id/entri/propo rsi, diakses 01 Mei 2019).

[2] Husen, Abrar, Manajemen Proyek : Perencanaan, Penjadwalan dan Pengendalian Proyek, Penerbit Andi, Yogyakarta, 2009.

[3] Ervianto, Wulfram I., Manajemen Proyek Konstruksi, Penerbit Andi, Yogyakarta, 2005.

[4] Saodang, Hamirhan, Hamirhan, Konstruksi Jalan Raya Buku 1 : Geomterik Jalan, Penerbit Nova, 2004.

[5] Mangare, J.B, dan Tarore, B.F.S, Kajian Proporsional Model Sumber Daya Proyek Konstruksi Gedung, Jurnal Ilmiah Media Engineering 2(3): 163-171, 2012.

[6] Muzayanah, Y, Pemodelan Proporsi Sumber Daya Proyek Konstruksi, Thesis, Magister Teknik Sipil Universitas Diponegoro, Semarang, 2008.

[7] Rostiyanti, Susy Fatena, Alat Berat Untuk Proyek Konstruksi, Rineka Cipta, Jakarta, 2008.

[8] Sarwono, Jonathan, Metode Penelitian Kuantitatif \& Kualitatif, Graha Ilmu, Yogyakarta, 2006. 